\title{
Flora do Ceará, Brasil: Combretaceae
}

\author{
Flora of Ceará, Brazil: Combretaceae
}

Raimundo Luciano Soares Neto $^{1}$, Luciana Silva Cordeiro ${ }^{2}$ \& Maria Iracema Bezerra Loiola ${ }^{3,4}$

\begin{abstract}
Resumo
Este estudo consiste no levantamento florístico de Combretaceae ocorrentes no estado do Ceará, como parte do projeto "Flora do Ceará". O estudo foi baseado na análise comparativa dos caracteres morfológicos de espécimes depositados em herbários, bibliografia, fotos de materiais-tipo, além de coletas e observações de campo. Foram registradas 17 espécies distribuídas em cinco gêneros: Buchenavia (2); Combretum (9); Conocarpus (1); Laguncularia (1) e Terminalia (4). As espécies ocorrem preferencialmente em ambientes mais secos como caatinga, carrasco e floresta estacional.
\end{abstract}

Palavras-chave: distribuição, florística, Combretum, nordeste do Brasil, Terminalia.

\begin{abstract}
We present the floristic survey of Combretaceae occurring in the Ceará state, as part of "Flora do Ceará" project. This study was based on the comparative analysis of morphological characters of herbarium specimens, bibliography, photo-type material, along with collections and field observations. Seventeen species in five genera were recorded: Buchenavia (2); Combretum (9); Conocarpus (1); Laguncularia (1) e Terminalia (4). The species occurs preferentially in drier habitats like the caatinga, carrasco and deciduous forest.

Key words: distribution, floristic, Combretum, Northeastern Brazil, Terminalia.
\end{abstract}

\section{Introdução}

Combretaceae compreende aproximadamente 500 espécies e 14 gêneros distribuídos nas regiões tropicais e subtropicais do mundo, sendo a África o principal centro de diversidade da família (Stace 2004, 2010). Está posicionada em Myrtales juntamente com outras 13 famílias (Stace 2010). Apresenta como grupo-irmão o clado formado por Lythraceae e Onagraceae (Tan et al. 2002; APG III 2009; Stace 2010). Seus representantes são caracterizados por apresentarem hábito lenhoso; tricomas lepidotos distintos nas porções vegetativas e reprodutivas; folhas simples, inteiras; flores tetrâmeras ou pentâmeras, sésseis ou subsésseis, ovário ínfero, unilocular com (1)2-8(20) óvulos com placentação apical e frutos indeiscentes, com 1 semente.

Em Combretaceae são reconhecidas duas subfamílias: Strephonematoideae, cujos representantes apresentam ovário semi-ínfero, compreende apenas o gênero Strephonema Hook.f., com três espécies de ocorrência exclusiva na África. Já Combretoideae, caracterizada por possuir ovário ínfero, abrange duas tribos de distribuição pantropical: Laguncularieae Engl. \& Diels e Combreteae DC., esta com duas subtribos: Terminaliinae (DC.) Exell \& Stace onde estão alocados os gêneros Buchenavia Eichler, Conocarpus L. e Terminalia L., e Combretinae Exell $\&$ Stace, destacando-se o gênero Combretum Loefl. entre seus representantes (Exell \& Stace 1996; Stace 2004; Sytsma 2004; Maurin et al. 2010).

Estudos moleculares suportam essa classificação, pois demonstram a monofilia de Laguncularieae e Combretinae (Tan et al. 2002; Maurin et al. 2010). Já na subtribo Terminaliinae, o gênero Terminalia é considerado parafilético com duas linhagens distintas e entre as modificações sugeridas por Maurin et al. (2010), os representantes de Buchenavia deveriam ser transferidos para Terminalia. Entretanto, esses dois táxons continuam sendo tratados como gêneros separados em estudos atuais sobre a família (Stace 2010; Marquete 2012).

\footnotetext{
${ }^{1}$ Universidade Federal do Rio Grande do Norte, Depto. Botânica, Ecologia e Zoologia, Campus Universitário, 59072-970, Natal, RN, Brasil.

${ }^{2}$ Universidade Federal do Ceará, Campus do Pici, 60455-970, Fortaleza, CE, Brasil.

${ }^{3}$ Universidade Federal do Ceará, Herbário EAC, bl. 906, Campus do Pici, 60455-970, Fortaleza, CE, Brasil.

${ }^{4}$ Autor para correspondência: iloiola@ufc.br
} 
No Brasil ocorrem 64 espécies em todas as regiões, sendo 13 endêmicas do país (Marquete 2012). Embora sejam registradas nos mais diversos domínios fitogeográficos e tipos de vegetação do país, as espécies são mais frequentes em ambientes úmidos, pois há registro de 47 espécies no domínio Amazônia, 29 no domínio da Mata Atlântica e 16 no domínio da Caatinga (Marquete 2012).

Estudos taxonômicos realizados em diferentes regiões brasileiras contribuíram para o conhecimento do grupo. Entre esses, destacamos os estudos de Marquete (1984, 1995), Marquete \& Valente (1997) e Marquete et al. (2003) que deram enfoque às espécies ocorrentes na região Sudeste; Linsigen et al. (2009) registraram as Combretaceae da Região Sul e no nordeste do país, Loiola \& Sales (1996) estudaram os representantes de Combretum ocorrentes em Pernambuco e Loiola et al. (2009) listaram as Combretaceae do estado da Paraíba. Já Marquete \& Valente (2010) apresentaram a lista atualizada das espécies de Combretaceae para o território brasileiro, acrescentando informações sobre os domínios fitogeográficos e tipos vegetacionais preferenciais das espécies, além de sinônimos.

Inserido no projeto "Flora do Ceará", o presente estudo tem como objetivo o levantamento florístico das espécies de Combretaceae no estado, contribuindo para um maior conhecimento da flora local e uma atualização da distribuição geográfica de alguns táxons brasileiros. Ressalta-se que especificamente para o Ceará, nenhum estudo sobre este grupo taxonômico havia sido realizado até o momento.

\section{Material e Métodos}

O estudo baseou-se na análise comparativa de amostras obtidas em campo e em espécimes depositados nos Herbários EAC, ESA, HST, HVASF, MO, R e VIC, siglas segundo Thiers (continuously updated). As identificações foram realizadas com o auxílio de bibliografia especializada (Marquete 1995; Loiola \& Sales 1996; Marquete et al. 2003; Stace 2010) e análise de imagens das coleções-tipo disponíveis no sítio do Herbário MOBOT (2013).

A terminologia para a descrição dos caracteres morfológicos seguiu Radford et al. (1974) e Stearn (1992). As flores foram medidas do pedicelo até o ápice das pétalas. Para terminologia dos frutos adotou-se Spjut (1994). Os nomes das espécies (incluindo as sinonímias) estão de acordo com Stace
(2010) e os nomes dos autores baseados no sítio do IPNI (2013). Já os dados referentes à forma de crescimento (hábito), habitat, período de floração e frutificação e nome popular foram obtidos dos rótulos das exsicatas e das observações em campo.

Os mapas de distribuição das espécies foram gerados através do programa DIVA-GIS (Hijmans et al. 2005), considerando-se os tipos vegetacionais propostos no Manual técnico da vegetação brasileira (IBGE 2012): Savana (cerrado), Savana estépica (caatinga/carrasco), Floresta Estacional Decidual (mata seca), Floresta Ombrófila Densa (mata úmida) e tabuleiros costeiros e manguezal.

\section{Resultados e Discussão}

Para o Ceará foram registradas 17 espécies distribuídas em cinco gêneros: Buchenavia (2), Combretum (9), Conocarpus (1), Laguncularia (1) e Terminalia (4). Destacamos que havia sido registrada a ocorrência de Buchenavia oxycarpa (Mart.) Eichler, B. pallidovirens Cuatrec. e Combretum vernicosum Rusby em território cearense (Stace 2010; Marquete 2012). No entanto, especula-se que $B$. oxycarpa provavelmente esteja extinta no estado, pois suas coletas datam de 1838 e 1910 e não há registros de coletas mais recentes. Portanto, decidimos não incluí-la nesse estudo. A análise do material de $B$. pallidovirens e C. vernicosum revelou que, na realidade, tais espécimes tratam-se de Buchenavia tetraphylla (Aubl.) R.A. Howard e Combretum mellifluum Eichler, respectivamente.

\section{Tratamento taxonômico}

Combretaceae R. Br., Prodr. Fl. Nov. Holl.: 351. 1810.

Árvores, arbustos ou lianas. Folhas opostas ou alternas, simples, inteiras, cobertas por tricomas compartimentados, escamosos ou glandulares; domácias presentes ou não. Inflorescências frequentemente espigas ou racemos, podendo formar panículas ou às vezes, capítulos globosos, terminais ou axilares. Bractéolas presentes. Flores actinomorfas ou zigomorfas, dioicas, tetrâmeras ou pentâmeras, hipanto dividido em duas partes: a inferior (envolvendo o ovário) e a superior (em tubo curto ou comprido terminando nos lobos do cálice); cálice 4-5 lobado, geralmente pouco desenvolvido; pétalas 4,5 ou ausentes, pequenas ou conspícuas, alternas com os lobos do cálice; androceu diplostêmone, estames 4-10, em dois verticilos, exsertos, filiformes, subulados 
ou truncados; anteras versáteis ou adnatas aos filetes, rimosas; disco nectarífero desenvolvido ou inconspícuo na base da parede do hipanto superior, margem glabra ou pilosa; ovário ínfero, unilocular, 2-6 rudimentos seminais pêndulos. Frutos indeiscentes, betulídios ou drupáceos, com duas, quatro ou cinco alas, menos frequente alas inconspícuas ou vestigiais.

\section{Chave de identificação das espécies de Combretaceae ocorrentes no Ceará}

1. Folhas opostas.

2. Hipanto inferior com 2 bractéolas adnatas na porção distal

4. Laguncularia racemosa

2'. Hipanto inferior sem bractéolas adnatas na porção distal.

3. Flores sem pétalas; estames 4, inclusos

2.3. Combretum glaucocarpum

3'. Flores com pétalas; estames 8 , exsertos.

4. Porções reprodutivas e vegetativas densamente cobertas por indumento tomentoso- viloso e poucos tricomas lepidotos

2.4. Combretum hilarianum

4'. Porções reprodutivas e vegetativas densamente cobertas apenas por tricomas lepidotos 5. Bractéola espatulada ou estreito-espatulada.

6. Fruto anfractuoso-plicado; alas sinuosas

2.1. Combretum duarteanum

6'. Fruto elíptico; alas planas

7. Tricomas lepidotos esbranquiçados a amarelados; hipanto superior crateriforme; disco nectarífero cônico ..... 2.5. Combretum lanceolatum

7'. Tricomas lepidotos ferrugíneos; hipanto superior infundibuliformecupuliforme; disco nectarífero em forma de anel

2.2. Combretum fruticosum

5'. Bractéola linear, estreito-oval ou lanceolada.

8. Pétalas lanceoladas

2.8. Combretum mellifluum

8'. Pétalas espatuladas, obovadas ou orbiculares.

9. Fruto orbicular

2.9. Combretum monetaria

9'. Fruto elíptico ou largamente elíptico.

10. Botão floral capitado; hipanto superior cupuliforme; fruto elíptico com alas estreitas (1-2 mm larg.)

2.6. Combretum laxum

10'. Botão floral turbinado; hipanto superior alongado-campanulado; fruto largamente elíptico com alas bem desenvolvidas (7-8 mm larg.)

2.7. Combretum leprosum

1'. Folhas alternas.

11. Árvores ou arbustos de manguezal; pecíolo com duas glândulas secretoras de sal

3. Conocarpus erectus

11'. Árvores ou arbustos de outros ambientes; pecíolo sem glândulas secretoras de sal.

12. Lobos do cálice inconspícuo ou pouco desenvolvidos; fruto drupáceo.

13. Folhas glabras, 2-8 pares de nervuras secundárias; fruto oval-elíptico, pontiagudo no ápice 1.1. Buchenavia tetraphylla

13'. Folhas com face abaxial tomentosa, 9-13 pares de nervuras secundárias; fruto arredondado 1.2. Buchenavia tomentosa

12'. Lobos do cálice desenvolvidos; fruto betulídeo, 2-5 alado.

14. Ramos com indumento ferrugíneo; frutos 5-alados ........ 5.3. Terminalia glabrescens

14'. Ramos glabros ou com indumento cinéreo; frutos 2-alados.

15. Lobos do cálice eretos

5.2. Terminalia fagifolia

15'. Lobos do cálice reflexos.

16. Folhas argênteo-tomentosas; frutos com alas arredondadas

5.1. Terminalia argentea

16'. Folhas glabras; frutos com alas oblongas ou subtriangulares 5.4. Terminalia mameluco 
1. Buchenavia Eichler, Flora 49: 164. 1866.

Árvores. Folhas alternas, aglomeradas no ápice dos ramos, geralmente obovadas ou oblanceoladas, base cuneada, ápice arredondado-emarginado. Inflorescências em espigas axilares, alongadas ou capitadas. Flores diminutas, hermafroditas e masculinas na mesma inflorescência. Hipanto inferior envolvendo o ovário e prolongado acima deste; hipanto superior cupuliforme, com cinco lobos do cálice pouco desenvolvidos. Pétalas ausentes. Estames 10, exsertos, inseridos em dois verticilos, filetes espessos e curtos; anteras adnatas aos filetes. Disco nectarífero viloso. Estilete curto; estigma truncado ou mais ou menos obtuso; ovário com 2-3 óvulos. Fruto drupáceo, geralmente elíptico, obovado ou arredondado.

Buchenavia compreende 20 espécies exclusivamente americanas, das quais 18 são restritas à América do Sul, sendo a bacia do rio Amazonas o centro de diversidade do gênero (Stace 2010). No Brasil, foram registradas 18 espécies de ampla distribuição, com maior diversidade (16 ssp.) ocorrendo no estado do Amazonas (Marquete 2012).

1.1. Buchenavia tetraphylla (Aubl.) R.A. Howard, J. Arnold Arbor. 64(2): 266. $1983 . \quad$ Fig.1a

Árvores ou arbustos 6-12 m alt.; com indumento glabro. Folhas 6,9-8,0 × 2,9-3,2 cm, glabras, lâmina obovada, ápice arredondado ou emarginado, base cuneada-atenuada; venação broquidódroma, 2-8 pares de nervuras secundárias; pecíolo 4-6 mm compr. Inflorescências 5,2-6,7 cm compr., espigas densifloras e capitadas, axilares ou terminais. Bractéola única, 1,5-2,0 $\times 1,0-1,2$ $\mathrm{mm}$, cimbiforme; botão floral 1,2-1,5 $\times 1,0-1,5$ $\mathrm{mm}$, capitado. Flores 3,0-4,5 × 3,0-3,5 mm, esverdeadas; hipanto inferior $1,5-2,0 \times 0,5-1,0$ $\mathrm{mm}$, obclavado, pubescente; hipanto superior 1,5-2,5 × 3,0-3,5 mm, cupuliforme, glabro; lobos do cálice inconspícuos; filetes do verticilo interno $1,5-2,0 \mathrm{~mm}$ compr., filetes do verticilo externo $2,0-2,5 \mathrm{~mm}$ compr.; anteras $0,5-0,7 \times 0,6-1,0$ $\mathrm{mm}$, cordiformes; disco nectarífero $0,5-1,0 \mathrm{~mm}$ compr., aneliforme, margem livre, viloso; ovário $0,5-1,0 \times 0,2-0,5 \mathrm{~mm}$; estilete 2,5-3,0 $\mathrm{mm}$ compr., linear; estigma truncado. Fruto 2,0-2,3 × 1,2-1,4 $\mathrm{cm}$, oval-elíptico, pontiagudo no ápice; pedicelo frutífero 1,1-1,8 cm compr.

Material examinado: Barbalha, Chapada do Araripe, 28.IV.2009, fr., J.R. Maciel et al. 1057 (EAC). Crato, Flona Araripe, 22.V.2002, fl., F. Silva (HST 14808).
É reconhecida pelo hipanto superior cupuliforme, anteras cordiformes e fruto drupáceo. Possui distribuição neotropical, ocorrendo de Cuba até o Rio de Janeiro (Weaver 1991). No Ceará, foi registrada em vegetação de carrasco, cerrado, complexo litorâneo, mata seca e mata úmida (Fig. 2). Floresce de agosto a novembro e frutifica de janeiro a outubro. Conhecida popularmente como amarelão, imbiritiba, minguiriba, mirindiba, murunduba.

1.2. Buchenavia tomentosa Eichler, Flora 49: 166. 1866.

Fig. 3a-c

Árvore $26 \mathrm{~m}$ alt., com indumento glabro. Folhas 8,4-9,0 × 4,0-5,2 cm, com face abaxial tomentosa, lâmina elíptica ou obovada, ápice arredondado ou retuso, base cuneada; venação broquidódroma, 9-13 pares de nervuras secundárias; pecíolo 4-6 mm compr. Inflorescências 2,7-3,2 cm compr., espigas densifloras, terminais e/ ou axilares. Bractéola única, 1,5-2,0 × 1,0-1,2 $\mathrm{mm}$, cimbiforme; botão floral 1,2-1,5 × 1,0-1,5 $\mathrm{mm}$, levemente capitado. Flores 2,0-2,5 mm, esverdeadas; hipanto inferior 1,0-2,5 × 0,2-0,3 $\mathrm{mm}$, cilíndrico, viloso; hipanto superior $0,9-1,5 \times$ 1,3-1,5 mm, cupuliforme; lobos do cálice pouco desenvolvidos; filetes do verticilo interno 1,5-2,0 $\mathrm{mm}$ compr., filetes do verticilo externo $2,0-2,5 \mathrm{~mm}$ compr.; anteras $0,5-0,7 \times 0,6-1,0 \mathrm{~mm}$, orbiculares; disco nectarífero $0,5-1,0 \mathrm{~mm}$ compr., aneliforme, margem livre, viloso; ovário $0,5-1,0 \times 0,2-0,5$ $\mathrm{mm}$; estilete 2,5-3,0 $\mathrm{mm}$ compr., linear; estigma agudo. Fruto 2,0-3,5 × 1,2-1,7 cm, arredondado; pedicelo frutífero $1,1-1,4 \mathrm{~cm}$ compr.

Material examinado: Crateús, RPPN Serra das Almas, 19.IX.2002, fl., F.S. Araújo \& J.R. Lima (EAC 33298). Novo Oriente, Planalto da Ibiapaba, 11.X.1991, fl., F.S. Araújo (EAC 19640).

Buchenavia tomentosa é reconhecida pela face abaxial tomentosa, inflorescência em espiga e frutos arredondados. Ocorre no Brasil, Bolívia e Peru (Stace 2010). No Ceará foi registrada em ambientes de carrasco, cerrado e mata seca (Fig. 2). Coletada com flores de agosto a outubro, e com frutos em maio e julho. Popularmente conhecida como mirindiba.

2. Combretum Loefl., Iter Hispan. App. 308. 1758. Árvores, arbustos ou subarbustos escandentes. Folhas opostas, com tricomas lepidotos em ambas as faces. Inflorescências em espigas, racemos ou panículas, axilares e/ou terminais. Flores hermafroditas, raramente unissexuadas. Hipanto inferior aderente ao ovário, sem bractéolas adnatas; 

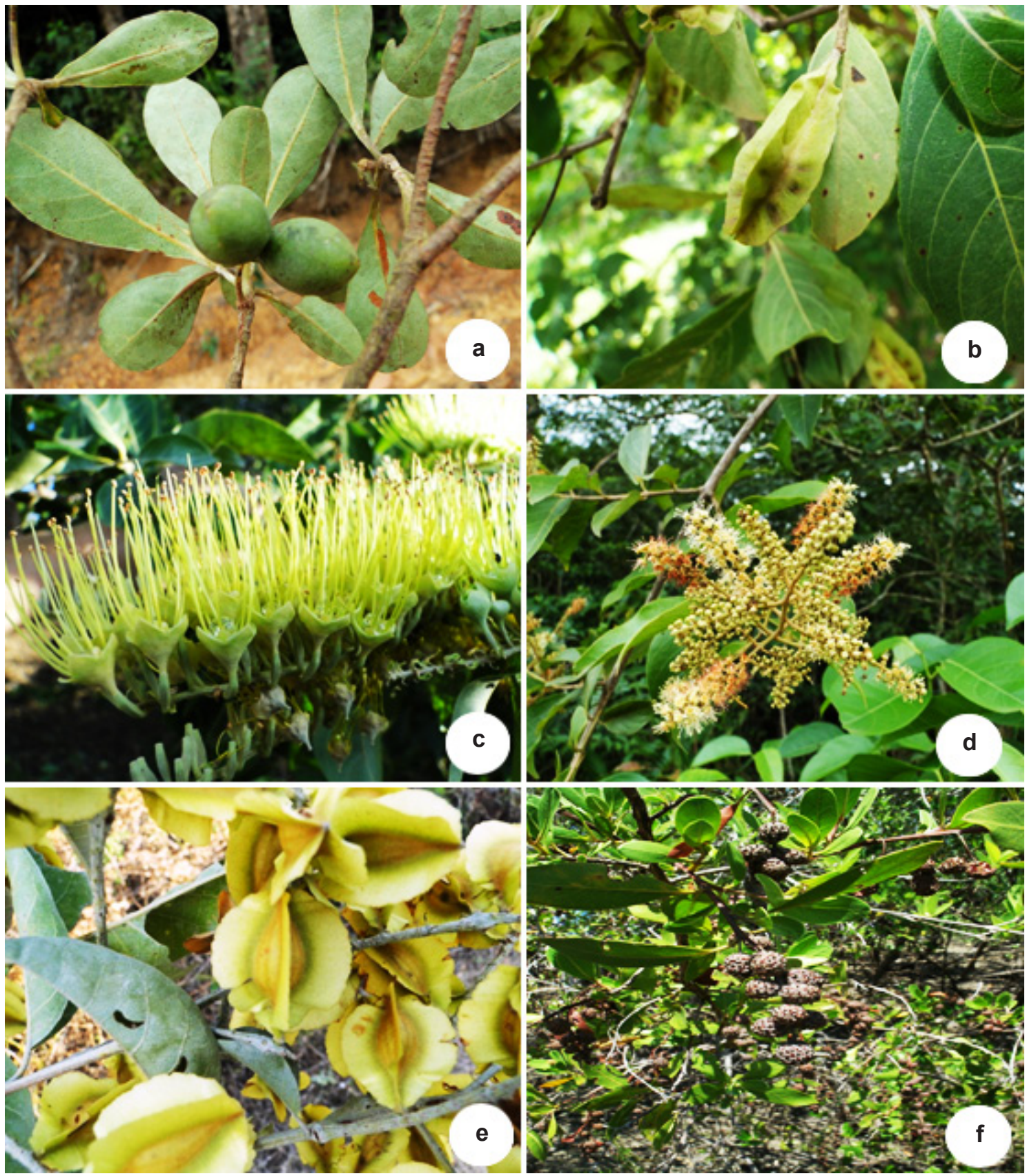

Figura 1 - a. Buchenavia tetraphylla - frutos maduros; b. Combretum duarteanum - fruto jovem; c. Combretum lanceolatum - inflorescência; d. Combretum mellifluum - hábito; e. Combretum leprosum - frutos; f. Conocarpus erectus - detalhe do ramo com infrutescência.

Figure 1 - a. Buchenavia tetraphylla - ripe fruit; b. Combretum duarteanum - young fruit; c. Combretum lanceolatum - inflorescence; d. Combretum mellifluum - habit; e. Combretum leprosum - fruits; f. Conocarpus erectus - detail of branch with infructescence.

hipanto superior em tubo curto ou comprido. Lobos do cálice 4; pétalas 4 inseridas na fauce do hipanto superior, entre os lobos do cálice ou raramente ausentes. Estames 4-8, exsertos, inseridos em dois verticilos; anteras versáteis, rimosas. Disco nectarífero desenvolvido ou não. Estilete exserto; estigma truncado ou mais ou menos obtuso; ovário com 2-6 óvulos. Fruto betulídeo, 4-alado. 


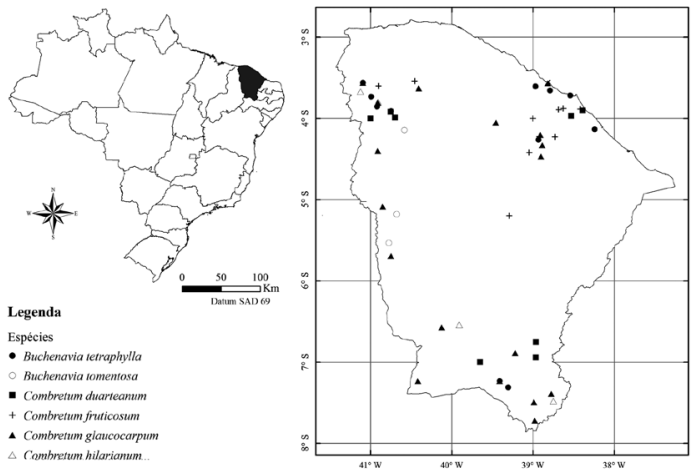

Figura 2 - Distribuição de Combretaceae no Ceará, Brasil: - Buchenavia tetraphylla; ○ B. tomentosa; $\square$ Combretum duarteanum; + C. fruticosum; $\boldsymbol{\Delta}$. glaucocarpum e $\Delta C$. hilarianum.

Figure 2 - Distribution of Combretaceae in Ceará state, Brasil: - Buchenavia tetraphylla; $\bigcirc$ B. tomentosa; $\square$ Combretum duarteanum; + C. fruticosum; $\boldsymbol{\Delta}$ C. glaucocarpum; $\Delta C$. hilarianum.

O gênero Combretum compreende 255 espécies com distribuição nas regiões tropicais e subtropicais da África, América e Ásia (Stace 2010). Das 29 espécies ocorrentes nas Américas, 21 tem registros no Brasil (Stace 2010; Marquete 2012) e nove no Ceará.

2.1. Combretum duarteanum Cambess., Fl. Bras. Merid. 2: 248. 1829.

Fig. 1b

Arvoretas ou arbustos 2,0-3,0 m alt., cobertos por tricomas lepidotos hialinos ou ferrugíneos. Folhas 7,4-10,4 × 3,9-6,6 cm, lâmina elíptica a largamente elíptica, ápice agudo ou acuminado, base cuneada; venação eucamptódroma-broquidódroma, 6-12 pares de nervuras secundárias; pecíolo $2-3 \mathrm{~mm}$ compr. Inflorescências 3,5-4,1 cm compr., racemos paucifloros, axilares. Bractéola única, 2,0-3,0 $\times$ $0,3-0,5 \mathrm{~mm}$, espatulada; botão floral $2,0-4,5 \times$ $1,0-1,5 \mathrm{~mm}$, turbinado. Flores 7,5-11,0 × 1,5-6,0 $\mathrm{mm}$, amareladas a avermelhadas; hipanto inferior $2,0-3,0 \times 1,0-2,0 \mathrm{~mm}$, fusiforme a levemente tetrágono; hipanto superior 5,5-8,0 × 1,5-6,0 mm, infundibuliforme-cupuliforme; lobos do cálice $0,5-1,0 \times 1,0-1,5 \mathrm{~mm}$, deltoides; pétalas 2,0-2,5 $\times 0,6-1,0 \mathrm{~mm}$, estreito-espatuladas a espatuladas; estames 8, exsertos; filetes do verticilo interno $5,0-8,0$ $\mathrm{mm}$ compr., filetes do verticilo externo $5,5-10,0 \mathrm{~mm}$ compr.; anteras $0,4-0,5 \times 0,5-0,6 \mathrm{~mm}$, elípticas; disco nectarífero $0,6-1,0 \mathrm{~mm}$ compr., aneliforme, margem livre, viloso; ovário $0,5-1,0 \times 0,6-0,8$ $\mathrm{mm}$; estilete $6,5-9,0 \mathrm{~mm}$ compr, filiforme; estigma truncado. Fruto 2,7-4,1 $\times 9,0-1,2 \mathrm{~mm}$, anfractuosoplicado; alas $25-39 \times 2-3,5 \mathrm{~mm}$, sinuosas, estreitas; pedicelo frutífero 1,0-3,0 cm compr.

Material examinado: Aquiraz, Serrote da Preaoca, 26.I.2001, fl., A.S.F. Castro 930 (EAC). Itaitinga, Serrote de Itaitinga, 22.XII.1955, fl., A. Ducke (EAC 1561). Lavras da Mangabeira, Colégio Agrícola, 17.V.1985, fr., A. Fernandes et al. (EAC 13177).

Combretum duarteanum é reconhecida pelo hipanto superior infundibuliforme-cupuliforme e frutos anfractuoso-plicados com alas sinuosas. Espécie exclusiva da América do Sul, com ocorrência na Bolívia, Brasil e Paraguai (Stace 2010). No Ceará ocorre em vegetação de caatinga arbustiva, cerrado e mata seca (Fig. 2). Coletada com flor em janeiro, março e dezembro e com fruto em janeiro, fevereiro, maio e julho. Ilustrações desta espécie são apresentadas em Loiola \& Sales (1996). Conhecida popularmente como mofumbode-louro, cipaúba, cipaúba-rasteira.

2.2. Combretum fruticosum (Loefl.) Stuntz, USDA Bur. Pl. Industr. Invente. Seeds 31: 86-87. 1914.

Fig. 2

Arbustos escandentes ou lianas 1,5-3,0 m alt., cobertos por tricomas lepidotos ferrugíneos. Folhas 8,0-10,1 × 4,7-7,2 cm, lâmina estreitamente elíptica a elíptica ou ovada, ápice acuminado ou agudo, base cuneada ou arredondada; venação geralmente eucamptódroma-boquidódroma, às vezes eucamptódroma ou broquidódroma, 5-10 pares de nervuras secundárias; pecíolo 5-6 $\mathrm{mm}$ compr. Inflorescências 4,2-8,4 cm compr., racemos densifloros, axilares e terminais. Bractéola única, $5,0-6,0 \times 1,0-1,2 \mathrm{~mm}$, estreito-espatulada; botão floral 4,0-4,5 × 1,5-2,5 mm, turbinado. Flores $11,0-15,5 \times 2,5-4,0 \mathrm{~mm}$, amareladas a avermelhadas; hipanto inferior 3,0-4,0 × 0,5-0,6 $\mathrm{mm}$, fusiforme, tetrágono; hipanto superior $8,0-11,0 \times 2,5-4,0 \mathrm{~mm}$, infundibuliformecupuliforme; lobos do cálice $2,1-2,5 \times 1,5-2,0$ $\mathrm{mm}$, triangulares; pétalas 2,0-3,0 × 1,0-1,5 mm, elípticas; estames 8 , exsertos; filetes do verticilo interno $16,5-18,0 \mathrm{~mm}$ compr., filetes do verticilo externo 17,0-19,0 mm compr.; anteras $1-1,5 \times$ $0,4-0,6 \mathrm{~mm}$, elípticas; disco nectarífero $1-1,5 \mathrm{~mm}$ compr., aneliforme, margem livre, densamente viloso; ovário $1,7-2,0 \times 0,4-0,5 \mathrm{~mm}$; estilete 20-23 mm compr., filiforme; estigma plano. Fruto $1,7-1,8 \times 1,5-1,8 \mathrm{~cm}$, elíptico; alas 1,6-1,8 $\times 5,0-10,0 \mathrm{~cm}$, planas, delgadas; região central 1,6-1,7 × 4,0-6,0 mm, apículo no ápice; pedicelo frutífero $0,2-0,6 \mathrm{~cm}$ compr. 


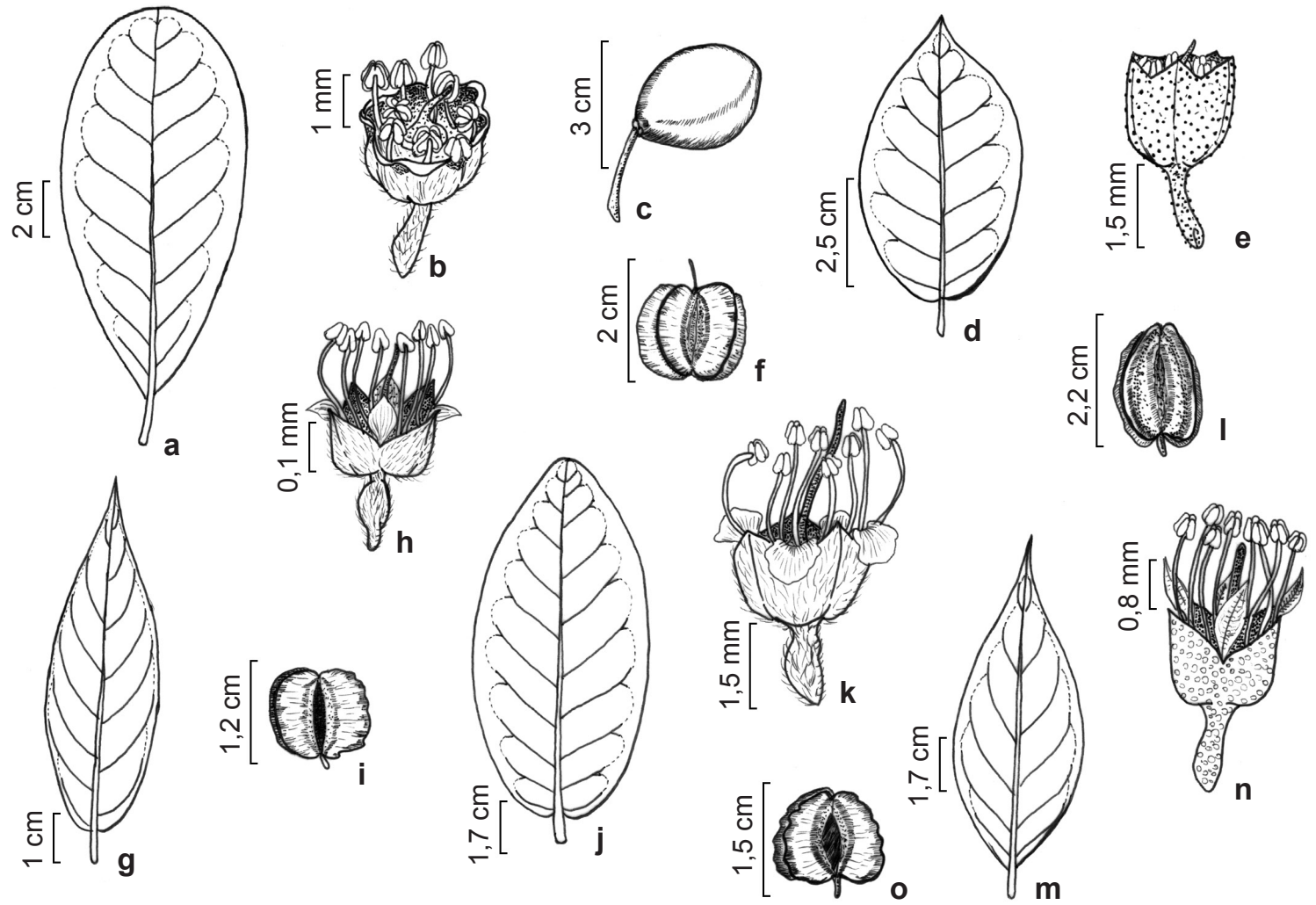

Figura 3 - a-c. Buchenavia tomentosa (F.S. Araújo s.n. EAC 19640) - a. face adaxial da folha, b. visão frontal da flor, c. fruto; d-f. Combretum glaucocarpum (F.S. Araújo s.n. EAC 15728) - d. face adaxial da folha, e. visão frontal da flor, f. fruto; g-i. Combretum hilarianum (P. Bezerra 545) - g. face adaxial da folha, h. visão frontal da flor, i. fruto; j-1. Combretum laxum (A.S.F. Castro 1151) - j. face adaxial da folha, k. visão frontal da flor, 1. fruto; m-o. Combretum mellifluum (A. Fernandes \& E. Nunes s.n. EAC 9868) - m. face adaxial da folha, n. visão frontal da flor, o. fruto.

Figure 3 - a-c. Buchenavia tomentosa (F.S. Araújo s.n. EAC 19640) - a. the adaxial leaf, b. frontal view of flower, c. fruit; d-f. Combretum glaucocarpum (F.S. Araújo s.n. EAC 15728) - d. the adaxial leaf, e. frontal view of flower, f. fruit; g-i. Combretum hilarianum (P. Bezerra 545) - g. the adaxial leaf, h. frontal view of flower, i. fruit; j-1. Combretum laxum (A.S.F. Castro 1151) - j.the adaxial leaf, k. frontal view of flower, 1. fruit; m-o. Combretum mellifluum (A. Fernandes \& E. Nunes s.n. EAC 9868) - m. the adaxial leaf, $\mathrm{n}$. frontal view of flower, o. fruit.

Material examinado: Caucaia, 23.VIII.2008, fl., $O$. Deusdênia \& E. Silveira (EAC 43054). Maranguape, Serra de Maranguape, 26.VI.1981, fl., E. Nunes \& P. Martins (EAC 10473). Pacoti, Serra de Baturité, Sítio Germinal, 30.VIII. 1941, fr., P. Bezerra 301 (EAC). Quixeramobim, 19.VIII.2003, fl., A. Fernandes \& E. Nunes (EAC 32879).

A espécie possui disco nectarífero conspícuo aneliforme, hipanto superior infundibuliformecupuliforme e tricomas lepidotos ferrugíneos, características que a diferenciam de Combretum lanceolatum Pohl ex. Eichler, espécie com maior similaridade morfológica. Ocorre no México, América Central e América do Sul (Linsigen et al. 2009). No Ceará está presente em floresta estacional semidecidual (Fig. 2). Floresce de maio a agosto e em outubro e frutifica em julho e agosto. Ilustrações desta espécie podem ser encontradas em Loiola \& Sales (1996). Popularmente conhecida como mofumbobranco, ramela-de-macaco e ramela-de-periquito.

\subsection{Combretum glaucocarpum Mart., Flora 24(2):} 3. 1841 .

Fig. 3d-f

Árvores, arbustos ou lianas 3,5-20,0 m de alt., cobertos por tricomas lepidotos hialinos ou amarelados. Folhas 5,7-7,3 × 3,8-4,0 cm, lâmina elíptica, ápice agudo ou acuminado, base arredondada ou cuneada; venação eucamptódroma a eucamptódroma-broquidódroma, 4-10 pares de nervuras secundárias; pecíolo 5-7 mm compr. Inflorescências 4,4-5,2 cm compr., panículas congestas, axilares e terminais. Bractéola única, 0,5-0,6 × 0,3-0,4 mm, dentiforme-subulada; 
botão floral 2,5-3,0 × 1,0-1,5 mm, globoso. Flores $3,5-4,0 \times 1,5-2,5 \mathrm{~mm}$, alaranjadas; hipanto inferior $1,0-1,5 \times 0,5-0,6 \mathrm{~mm}$, fusiforme, levemente tetrágono; hipanto superior 2,0-3,0 × 1,5-2,5 mm, campanulado; lobos do cálice ausentes ou 4 , muito curtos; pétalas ausentes; estames 4 , inclusos, todos do mesmo tamanho; filetes 1,5-2,0 mm compr.; anteras $0,4-0,5 \times 0,5-0,6 \mathrm{~mm}$, cordiformes; disco nectarífero $0,5-0,6 \mathrm{~mm}$ compr., aneliforme, margem livre, viloso; ovário $0,6-1,0 \times 0,4-0,5 \mathrm{~mm}$ compr.; estilete 2,5-3,0 mm, filiforme; estigma plano. Fruto $1,6-2,1 \times 2,0-2,4 \mathrm{~cm}$, elíptico a largamente elíptico; alas 1,4-1,5 × 6,0-8,0 mm, planas, delgadas; região central 1,6-2,0 × 5-7 mm, apículo no ápice; pedicelo frutífero $2,1-2,3 \mathrm{~cm}$ compr.

Material examinado: Crato, Avenida Pedro Felício Cavalcante, 17.VIII.2008, fr., M.A.P. Silva 47359 (EAC); Fortaleza, Campus do Pici, 29.III.1977, f1., L.Z. Almeida (EAC 3121). Meruoca, Serra da Meruoca, 19.V.1989, fr., A. Fernandes (EAC 16152). Novo Oriente, Morro dos Três Irmãos, 20.II.1989, fl., F.S. Araújo (EAC 15728).

A espécie caracteriza-se por possuir flores diminutas $(3,5-4 \times 1,5-2,5 \mathrm{~mm})$ com hipanto superior campanulado, lobos do cálice ausentes ou quatro, muito curtos e flores sem pétalas. É exclusiva da América do Sul, ocorrendo na Bolívia, Brasil e Peru (Stace 2010). No Ceará, foi encontrada em vegetação de carrasco, caatinga arbórea, mata seca e complexo litorâneo em mata de tabuleiro (Fig. 2). Coletada com flores nos meses de fevereiro a abril, junho e dezembro, e com frutos de maio a setembro. Conhecida popularmente como cipaúba, cipaúba-de-boi e sipaúba.

2.4. Combretum hilarianum D.Dietr., Syn. Pl. 2: 1303.1840 .

Fig. 3g-i

Arbustos escandentes $4,0 \mathrm{~m}$ alt., com estruturas reprodutivas e vegetativas densamente cobertas por indumento tomentoso-viloso e poucos tricomas lepidotos amarelados a ferrugíneos. Folhas 5,9-7,7 × 2,3-3,0 cm, lâmina estreitamente elíptica ou elíptica, ápice agudo ou acuminado, base cordada ou obtusa; venação eucamptódroma a eucamptódroma-broquidódroma, 6-11 pares de nervuras secundárias; pecíolo $2-5 \mathrm{~mm}$ compr. Inflorescências 5,8-9,0 cm compr., racemos densifloros, terminais e/ou axilares. Bractéola única, 1,5-2,0 × 0,8-1,0 mm, elíptica; botão floral $3,0-3,5 \times 1,5-2,0 \mathrm{~mm}$, elipsoide-arredondado. Flores 3,5-4,0 × 2,0-3,0 mm, esverdeadas; hipanto inferior 1,5-2,5 × 1,2-1,5 mm, fusiforme; hipanto superior $1,5-2,0 \times 2,8-3,2 \mathrm{~mm}$, cupuliforme; lobos do cálice $0,5-1,0 \times 0,5-1,0 \mathrm{~mm}$, deltoides; pétalas 1,0-1,5 × 1,0-1,2 mm, obovadas; estames 8 , exsertos; filetes do verticilo interno $3,5-5,0$ mm compr., filetes do verticilo externo $3,0-4,5$ $\mathrm{mm}$ compr.; anteras 0,5-0,6 $\times 0,5-0,7 \mathrm{~mm}$, cordiformes; disco nectarífero $0,6-1,0 \mathrm{~mm}$ compr., aneliforme, margem livre, densamente viloso; ovário $0,8-1,0 \times 0,4-0,5 \mathrm{~mm}$; estilete $2-3,5 \mathrm{~mm}$ compr., filiforme; estigma truncado. Fruto $1,0-1,2$ $\times 1,0-1,4 \mathrm{~cm}$; alas $0,8-1,0 \times 0,4-0,5 \mathrm{~mm}$, planas; região central 10-11 × 4-6 mm, ápice sem apículo; pedicelo frutífero $0,5-1,0 \mathrm{~cm}$ compr.

Material examinado: Saboeiro, entre Bebedouro e Saboeiro, 2.VI.1943, fr., P. Bezerra 545 (EAC). Ubajara, Cachoeira do Boi Morto, 22.III.1980, fl., A. Fernandes \& P. Martins (EAC 8281).

Combretum hilarianum é a única espécie da família no Ceará que possui indumento tomentosoviloso, além dos tricomas lepidotos recobrindo o caule, folhas, flores e frutos. Ocorre no Brasil, Bolívia, Paraguai e Peru (Stace 2010). No Ceará, foi registrada em vegetação de caatinga e carrasco (Fig. 2). A espécie é conhecida de poucas coletas no estado. Floresce e frutifica em março e junho, respectivamente. Nome popular: mofumbo.

2.5. Combretum lanceolatum Pohl ex Eichl., in: Mart. Fl. bras. 14(2): 110. $1867 . \quad$ Fig. 1c Arvoretas a arbustos escandentes $2,5-5,0 \mathrm{~m}$ alt., densamente cobertos por tricomas lepidotos esbranquiçados a amarelados. Folhas 9,8-11,1 $\times$ 3,5-4,2 cm, lâmina lanceolada ou ovada, ápice acuminado ou agudo, base cuneada; venação geralmente eucamptódroma-boquidódroma, às vezes eucamptódroma ou broquidódroma, 5-10 pares de nervuras secundárias; pecíolo $3-5 \mathrm{~mm}$ compr. Inflorescências 6,9-15,7 cm compr., racemos densifloros e congestos, terminais e/ ou axilares. Bractéola única, 3,5-6,0 × 1,0-1,5 $\mathrm{mm}$, espatulada; botão floral $6,0-7,0 \times 2,0-3,5$ $\mathrm{mm}$, capitado. Flores 12,5-13,5 × 3,5-7,0 mm, esverdeadas a amareladas; hipanto inferior 4,5-5,0 $\times 0,5-1,0 \mathrm{~mm}$, tetrágono; hipanto superior $8,0-8,5$ $\times 5,0-7,0 \mathrm{~mm}$, crateriforme; lobos do cálice $2,0-3,0 \times 2,5-3,0 \mathrm{~mm}$, deltoides; pétalas $1,5-1,9$ $\times 1,0-1,5 \mathrm{~mm}$, suborbiculares a orbiculares; estames 8 , exsertos; filetes do verticilo interno 17,0-21,0 mm compr., filetes do verticilo externo 19,0-20,0 mm compr.; anteras $1,0-1,5 \times 0,8-1,0$ $\mathrm{mm}$, elípticas; disco nectarífero $1,5-2,0 \mathrm{~mm}$ compr., cônico, margem livre, pubescente; ovário $1,5-1,7 \times 0,4-0,5 \mathrm{~mm}$; estilete $30-34 \mathrm{~mm}$ compr., filiforme; estigma agudo. Fruto 1,6-1,9 × 1,3-1,4 $\mathrm{cm}$, elíptico; alas 1,5-1,7 × 3,0-5,0 cm, planas; 
região central $16,5-19 \times 3,5-4 \mathrm{~mm}$, apículo no ápice; pedicelo frutífero 0,4-0,6 $\mathrm{cm}$ compr.

Material examinado: Aiuaba, Estação Ecológica, 22.XI.1982, fl., F. de A. Viana (EAC 11951). Granja, à beira de um riacho, 20.X.1988, fr., M. Andrade Neto (EAC 15776). Quixadá, 23.VI.1946, fl., P. Bezerra (EAC 814).

É reconhecida pelo hipanto superior crateriforme e pelo disco nectarífero cônico. Ocorre no Brasil, Bolívia e Paraguai (Stace 2010). No Ceará, foi encontrada em vegetação de caatinga arbustiva e mata ciliar (Fig. 4). Registrada com flores em março e de maio a dezembro e com frutos de agosto a novembro. Popularmente conhecida por cipó-do-rio, jerimataia, mofumbo, mofumbodo-rio, mofumbo-vermelho e remela-de-macaco.

2.6. Combretum laxum Jacq. Enum. Syst. P1. 19. 1760 .

Fig. 3j-1

Árvores, arbustos escandentes ou lianas 3,5 $\mathrm{m}$ alt., cobertos por indumento lepidoto ferrugíneo. Folhas 9,3-13,0 × 3,6-4,9 cm, lâmina elíptica ou oblanceolada, ápice acuminado a longamente acuminado ou arredondado, base cuneada ou obtusa; venação geralmente eucamptódromabroquidódroma, às vezes eucamptódroma ou broquidódroma, 6-14 pares de nervuras secundárias; pecíolo 6-10 $\mathrm{mm}$ compr. Inflorescências 3,3-5,2 cm compr., panículas laxas ou congestas, terminais ou axilares. Bractéola única, $0,8-1,0 \times 0,1-0,3 \mathrm{~mm}$, linear; botão floral 2,4-3,0 × 1,0-1,5 mm, capitado. Flores 2,5-4,0 × 2,0-2,5 mm, esbranquiçadas ou amareladas; hipanto inferior 1,0-2,0 × 0,5-1,0 $\mathrm{mm}$, fusiforme, tetrágono; hipanto superior 1,5-2,0 × 2,0-2,5 mm, cupuliforme; lobos do cálice $0,3-0,5 \times 0,4-0,5 \mathrm{~mm}$, triangulares; pétalas $1,0-1,5 \times 1,0-2,0 \mathrm{~mm}$, orbiculares; estames 8 , exsertos; filetes do verticilo interno $2,5-3,5 \mathrm{~mm}$ compr., filetes do verticilo externo 3,0-4,0 mm compr.; anteras 0,5-0,8 × 0,5-0,6 mm, largamente elípticas; disco nectarífero 0,4-0,6 mm compr., aneliforme, margem livre, glabro; ovário 0,5-0,6 × 0,3-0,5 mm; estilete 1,0-3,0 mm compr, filiforme; estigma truncado. Fruto 1,7-2,0 × 0,7-1,1 cm, elíptico; alas 1,5-1,8 × 0,1-0,2 cm, planas, estreitas; região central $1,7-2,0 \times 0,5-0,9 \mathrm{~mm}$, aguda; pedicelo frutífero $0,2-1,2 \mathrm{~cm}$ compr.

Material examinado: Eusébio, Margem da lagoa da Precabura, 28.XII.2001, fr., A.S.F. Castro 1151 (EAC). Graça, Passagem Larga, 31.VIII.2006, fl., A.S.F. Castro 1848 (EAC). Granja, s.1., 20.X.1988, fr., M. Andrade Neto (EAC 15809). Ubajara, Parque Nacional de Ubajara, 18.IX.1988, fl., A. Fernandes (EAC 15651).
Esta espécie é reconhecida pelos lobos do cálice curtos $(0,3-0,5 \times 0,4-0,5 \mathrm{~mm})$, pétalas orbiculares e frutos elípticos com alas estreitas (0,1-0,2 cm larg.). Espécie exclusivamente Neotropical, ocorrendo do México a Argentina (Linsingen et al. 2009). No Ceará, está presente em vegetação de caatinga, carrasco, cerrado, mata ciliar e mata seca (Fig. 4). Coletada com flor de agosto a outubro, e com frutos em janeiro e de agosto a dezembro. Nomes populares: cipó-do-rio, mofumbo.

2.7. Combretum leprosum Mart., Flora 24(2): 1. 1841.

Fig. 1e

Arvoretas, arbustos escandentes ou lianas 2,5-5,0 $\mathrm{m}$ alt., cobertos com indumento lepidoto esbranquiçado ou amarelado. Folhas 6,9-8,5 × 3,9-5,6 cm, lâmina elíptica a largamente elíptica, ápice agudo, acuminado ou arredondado, base arredondada; venação eucamptódroma a broquidódroma, geralmente eucamptódroma-broquidódroma, 5-12 pares de nervuras secundárias; pecíolo 10-12 mm compr. Inflorescências 4,7-10,9 cm compr., panículas de racemos congestas, terminais e axilares. Bractéola única 2,5-5,0 × 0,5-0,6 mm, linear; botão floral, $4,0-5,0 \times 1,0-1,2 \mathrm{~mm}$, turbinado. Flores 6,5-8,0 $\times$ 2,5-3,0 mm, esbranquiçadas a amareladas; hipanto inferior 2,0-3,0 × 1,0-1,2 $\mathrm{mm}$, fusiforme; hipanto superior 4,5-5,0 × 2,5-3,0 mm, alongadocampanulado; lobos do cálice 1,2-2,0 × 1,0-1,5 $\mathrm{mm}$, triangulares; pétalas 1,8-2,0 × 1,2-1,4 mm, orbiculares; estames 8 , exsertos; filetes do verticilo

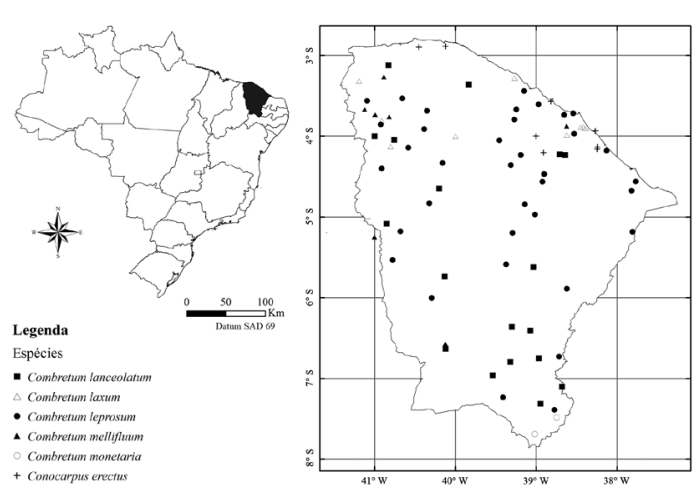

Figura 4 - Distribuição de Combretaceae no Ceará, Brasil: - Combretum lanceolatum; $\Delta$ C. laxum; C. leprosum; $\boldsymbol{\Delta}$ C. mellifluum; O C. monetaria; + Conocarpus erectus.

Figure 4 - Distribution of Combretaceae in Ceará state, Brasil: - Combretum lanceolatum; $\Delta$ C. laxum; $\bullet$ C. leprosum; $\Delta$ C. mellifluum; ○ C. monetaria; + Conocarpus erectus. 
interno 4-6 mm compr., filetes do verticilo externo 3,5-4,0 mm compr.; anteras 0,5-1,0 × 0,3-0,6 $\mathrm{mm}$, elípticas; disco nectarífero $0,8-1 \mathrm{~mm}$ compr., infundibuliforme, margens não livres, densamente viloso; ovário 1,0-1,2 × 0,4-0,5 mm; estilete 7-9 mm compr., filiforme; estigma agudo. Fruto 1,7-2,2 × 1,5-1,8 cm, largamente elíptico; alas $1,4-1,7 \times 0,7-0,8 \mathrm{~cm}$, planas, secas; região central $1,7-2,2 \times 0,5-0,6 \mathrm{~mm}$, ápice sem apículo; pedicelo frutífero $0,5-1,0 \mathrm{~cm}$ compr.

Material examinado: Caridade, Campos Belos, estrada de Inhuporanga para Guaramiranga, 3.VII.2008, fr., M.O.T. Menezes 12 (EAC). Novo Oriente, Milagres, 10.III.1991, fl., F.S. Araújo 336 (EAC). Sobral, Fazenda Macapá, Taperoaba, 18.VI.1994, fr., M. Andrade Neto (EAC 21252)

Espécie facilmente reconhecida pelos tricomas lepidotos esbranquiçados ou amarelados recobrindo ramos, folhas, flores e frutos; hipanto superior alongado campanulado e pétalas orbiculares. Tem distribuição exclusiva na América do Sul, com registro para Bolívia, Paraguai e Brasil (Loiola et al. 2009). No estado do Ceará tem ampla distribuição, com ocorrência em vegetação de caatinga arbustiva, carrasco, cerrado e no complexo litorâneo na mata de tabuleiro (Fig. 4). Floresce e frutifica o ano todo. Conhecida popularmente como mofumbo, mofumbo-branco e mufumbo.

2.8. Combretum mellifluum Eichler, Fl. bras. 14(2): 113. 1867.

Figs. 1d, 3m-o

Árvores ou arbustos escandentes $8 \mathrm{~m}$ alt., cobertos por tricomas lepidotos esbranquiçados. Folhas 5,1-6,5 × 2,4-3,9 cm, lâmina elíptica a largamente elíptica, ápice acuminado ou agudo, base cuneada ou obtusa; venação eucamptódromabroquidódroma, 4-8 pares de nervuras secundárias; pecíolo 4-7 mm compr. Inflorescências 4,4-7,2 cm compr., panículas de racemos laxas, terminais ou axilares. Bractéola única, 1,0-1,5 × 0,4-0,6 mm, lanceolada; botão floral 2,0-2,5 × 1,0-1,2 mm, capitado ou turbinado. Flores 3,0-3,5 × 2,0-2,5 $\mathrm{mm}$, amareladas; hipanto inferior 1,0-1,5 × 0,5-0,6 $\mathrm{mm}$, tetrágono; hipanto superior 1,5-2,5 × 2,0-2,5 $\mathrm{mm}$, infundibuliforme-cupuliforme; lobos do cálice 1,0-1,5 × 0,8-1,0 mm, triangulares; pétalas 1,4-2,0 × 0,5-0,7 mm, lanceoladas; estames 8 , exsertos; filetes do verticilo interno $2-4 \mathrm{~mm}$ compr., filetes do verticilo externo $1,5-3,5 \mathrm{~mm}$ compr.; anteras $0,5-0,6 \times 0,4-0,5 \mathrm{~mm}$, elípticas; disco nectarífero $0,2-0,3 \mathrm{~mm}$ compr., aneliforme, margens livres, viloso; ovário $0,5-0,6 \times 0,2-0,3$ $\mathrm{mm}$; estilete 2,5-4,2 mm compr., filiforme; estigma agudo. Fruto $1,3-1,5 \times 1,0-1,2 \mathrm{~cm}$, elíptico; alas $1,1-1,3 \times 2,5-4,0 \mathrm{~cm}$, planas; região central 1,3-1,5 × 0,4-0,5 cm, ápice sem apículo; pedicelo frutífero 0,2-0,3 cm compr.

Material examinado: Reriutaba, estrada para Guaraciaba do Norte, 7.III.1981, fl. e fr., A. Fernandes \& E. Nunes (EAC 9868). Tianguá, em local não determinado, 18.II.1977, fl., A. Fernandes \& Matos (EAC 3196).

Pode ser reconhecida pela flor com hipanto superior infundibuliforme-cupuliforme e pétalas lanceoladas. Ocorre no Paraguai, Peru, Bolívia e Brasil (Stace 2010). No Ceará, foi registrada em vegetação de caatinga, carrasco, cerrado, mata seca e mata úmida (Fig. 4). Coletada com flores de fevereiro a junho, e com frutos de fevereiro a março. Nomes populares: cipaúba e mofumbo.

2.9. Combretum monetaria Mart., Flora, 24(2): Beibl. 2. 1841.

Fig. 5a-c

Arvoreta 2-4 m alt.; coberta por tricomas lepidotos hialinos ou ferrugíneos. Folhas 2,2-6,0 $\times$ 1,7-3,0 cm, lâmina elíptica a largamente elíptica; ápice agudo, às vezes caudado, base cuneada; venação eucamptódroma-broquidódroma, 4-8 pares de nervuras secundárias; pecíolo 2-3 mm compr. Inflorescências 2,0-4,5 cm compr., racemos subcapitados, axilares e/ou terminais. Bractéola única, 1,0-1,5 × 1,0 mm, linear a estreito oval; botão floral 1,5-2,0 × 1,0-1,5 mm, capitado a turbinado. Flores 7,0-8,0 × 2,5-3,2 $\mathrm{mm}$; hipanto inferior 1,5-2,0 $\times 0,4-0,5 \mathrm{~mm}$, ovoide; hipanto superior 2,0-2,5 × 1,5-2,0 mm, infundibiliforme-cupuliforme; lobos do cálice $0,5-1,0 \times 1,0-1,5 \mathrm{~mm}$, deltoides; pétalas 1,0-1,5 $\times 0,4-0,5 \mathrm{~mm}$, espatuladas ou obovadas; estames 8 , exsertos; filetes do verticilo interno 3,0-3,5 $\mathrm{mm}$ compr., filetes do verticilo externo 3,5-4,0 $\mathrm{mm}$ compr.; anteras $0,4-0,5 \times 0,3-0,4 \mathrm{~mm}$, elípticas; disco nectarífero $0,6-1,0 \mathrm{~mm}$ compr., aneliforme, margem livre, viloso; ovário 0,4-0,6 $\times$ 1-1,2 mm; estilete 3-3,5 mm compr., filiforme; estigma punctiforme. Fruto 1,0-1,4 × 0,3-0,4 cm, orbicular; alas 0,9-1,0 × 0,2-0,3 cm, reflexas; região central $0,5-0,6 \times 0,1-0,2$, aguda; pedicelo frutífero $0,1-1,5 \mathrm{~m}] \mathrm{cm}$ compr.

Material examinado: Jati, estrada para DNOCS, 3.II.2009, fl., J.G. Carvalho-Sobrinho 1861 (HVASF). Mauriti, área testemunho da ASV Pedreira, ca. $1 \mathrm{~km}$ do canal da transposição, 8.V.2012, fr., V.M. Cotarelli 1725 (HVASF).

Reconhecida pelas flores com pétalas espatuladas ou obovadas e principalmente pelo fruto orbicular. Espécie endêmica do Brasil, com 
ocorrência na Bahia, Minas Gerais, Paraíba e Pernambuco (Marquete 2012). Coletada no Ceará em vegetação de caatinga (Fig. 4), com flores em fevereiro e frutos em maio. Ausência de registro de nome popular para essa espécie. Popularmente conhecida como mofumbo e sipaúba.

\section{Conocarpus erectus L., Sp. Pl. 1: 176-177.} 1753.

Fig. $1 \mathrm{f}$

Árvores ou arbustos $3 \mathrm{~m}$ alt. Folhas 6,3-7,0 $\times$ 1,9-2,4 cm, alternas, lâmina lanceolada ou oblanceolada, ápice agudo ou arredondado, base cuneada; venação broquidódroma, 4-7 pares de nervuras secundárias; domácias lentibuliformes nas axilas das nervura primária com as secundárias na face abaxial; pecíolo 6-12 $\mathrm{mm}$, com duas glândulas secretoras de sal. Inflorescências 4-6 $\times$ 5-6 mm, capítulos globosos, terminais e/ou axilares. Bractéola única 2,5-4,5 × 0,5-1,0 mm, lanceolada; botão floral não observado. Flores 1,9-2,4 × 1,0-1,2 mm, marrons; hipanto inferior $1-1,5 \times 1-1,5 \mathrm{~mm}$, assimétrico, côncavo convexo, tomentoso no ápice, glabro na base; hipanto superior $0,8-1,0 \times 0,9-1,2 \mathrm{~mm}$, cupuliforme, esparsamente tomentoso; lobos do cálice 5, 0,8-1 $\times$ 0,5-0,8 mm, ovado-triangulares; pétalas ausentes; estames 5, inclusos, em único verticilo, filetes 1,0-1,3 mm compr., filiforme; anteras 0,3-0,4 $\times$ 0,2-0,5 mm, orbiculares; disco nectarífero 0,3-0,5 $\mathrm{mm}$, aneliforme, margem livre, pubescente; ovário 0,8-1 × 0,3-0,5 mm; estilete 0,9-1,2 mm compr., encurvado; estigma truncado. Fruto 2,5-4,0 $\times$ 2,0-3,0 cm, imbricado, reflexo, geralmente hipanto superior persistente,subséssil.

Material examinado: Caucaia, Parque Botânico do Ceará, 25.III.1998, fr., E. Nunes et al. (EAC 26246). Fortaleza, salinas, Barra do Ceará, 17.X.1976, fl., L. Almeida (EAC 2931). Iguape, 7.I.1977, fl., A. Fernandes \& M. Ferri (EAC 3074). Jijoca de Jericoacoara, APA de Jericoacoara, 7.III.1997, fr., L.Q. Matias 19 (EAC).

Conocarpus erectus pode ser facilmente reconhecida pelas flores e frutos agrupados em capítulos globosos. Ocorre no litoral meridional da Flórida, México, América Central e na mérica do Sul se desenvolve no litoral do Equador ao Brasil (Linsigen et al. 2009). Sempre associada a ambientes de manguezal. No Brasil, foi registrada nos estados do Pará, Alagoas, Bahia, Maranhão, Paraíba, Pernambuco, Piauí, Rio Grande do Norte, Sergipe, Espírito Santo, São Paulo, Rio de Janeiro e Paraná (Marquete 2012). No Ceará foi registrada ao longo do litoral (Fig. 4) em manguezais. Coletada com flor de janeiro a abril, em junho, julho e outubro e com frutos de fevereiro a julho. Popularmente conhecida como mangue-de-botão, mangue-ratinho.

4. Laguncularia racemosa (L.) C.F. Gaertn., Suppl. Carp. 3: 209, t. 217. $1807 . \quad$ Fig. 6

Árvores 3,0-6,0 m alt., com indumento glabro. Folhas 5,4-6,3 × 3,7-4,2 cm, opostas, lâmina elíptica ou obovada, ápice emarginado ou obtuso, base obtusa; venação broquidódroma, 9-18 pares de nervuras secundárias; pecíolo 7-12 mm compr., com duas glândulas secretoras de sal. Inflorescências 5,4-7,9 cm compr., racemos de espigas laxifloras, terminais ou axilares. Bractéola única, 1,5-2,0 × 1,5-2,0 mm, cimbiforme; botão floral não observado. Flores 4,0-4,5 × 3,0-3,5 mm, monóicas ou estaminadas, esverdeadas; hipanto inferior 2,0-2,5 × 1,5-2,0 mm, campanulado, com duas bractéolas adnatas à porção distal; hipanto superior 2,0-2,5 × 3,0-3,5 mm, cupuliforme; lobos do cálice $5,1,0-1,2 \times 1,0-1,5 \mathrm{~mm}$, triangulares; pétalas $1,0-1,2 \times 1,2-1,5 \mathrm{~mm}$, orbiculares; estames 10 , inclusos, em um único verticilo, filetes $0,6-1,0$ $\mathrm{mm}$ compr.; anteras $0,5-0,6 \times 0,4-0,5 \mathrm{~mm}$, cordiformes; disco nectarífero $0,5-1 \mathrm{~mm}$ compr., aneliforme, com margens livres, viloso; ovário $1-1,5 \times 0,5-0,8 \mathrm{~mm}$; estilete $2-2,5 \mathrm{~mm}$ compr., filiforme; estigma capitado. Fruto $1,3-1,5 \times$ 0,4-0,5 mm, nucoide, obovado, estriado, lobos do cálice persistentes; pedicelo frutífero inconspícuo. Material examinado: Aquiraz, Praia do Presídio, 15.II.1997, fr., A.S.F. Castro 338 (EAC). Beberibe, Morro Branco, 7.I.1977, fl., P. Bezerra \& A. Fernandes (EAC 3071). Fortaleza, Mangue do Caça e Pesca, 22.V.1990, fr., F. Cavalcanti (EAC 16607). São Gonçalo do Amarante, Pecém, 12.XII.1998, fl., D. de S. Sampaio(EAC 27471).

Espécie reconhecida pela presença de glândulas secretoras de sal no pecíolo, pela flor com hipanto inferior campanulado com duas bractéolas adnatas à porção distal e pelos frutos nucoides e estriado. Ocorrência semelhante à de Conocarpus erectus, ocorrendo no litoral meridional da Flórida, México, América Central e na América do Sul se desenvolve no litoral do Equador ao Brasil (Linsigen et al. 2009). No Ceará ocorre ao longo do litoral (Fig. 6). Coletada com flor de janeiro a abril, em setembro e dezembro, e com frutos o ano inteiro. Ilustrações desta espécie estão disponíveis em Linsingen et al. (2009). Nomes populares: mangue-branco, manguemanso, mangue-de-sapateiro. 

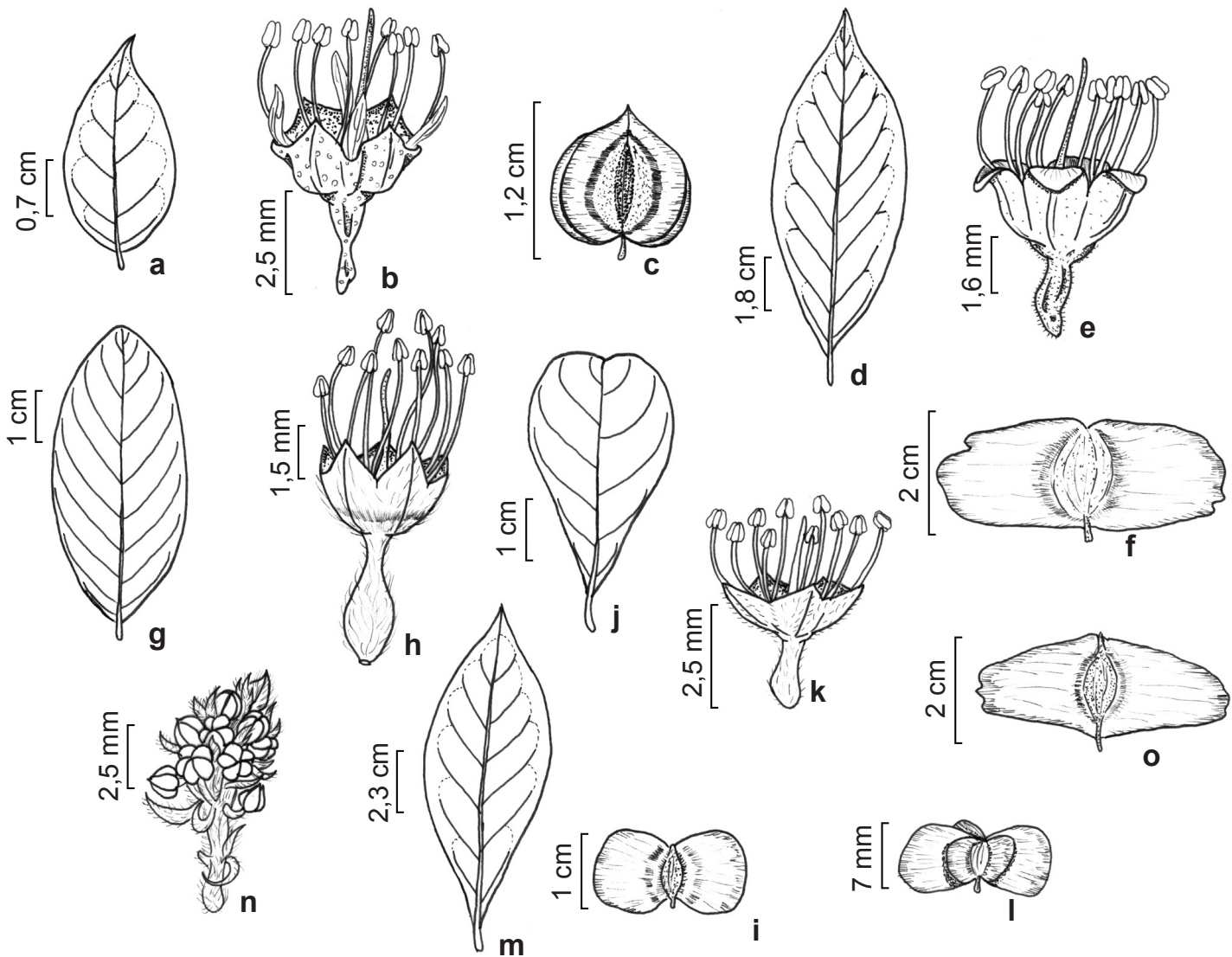

Figura 5 - a-c. Combretum monetaria - a. face adaxial da folha; b. visão frontal da flor (J.G. Carvalho-Sobrinho1861); c. fruto. d-f. Terminalia argentea (B. Dubs 1731) - d. face adaxial da folha; e. visão frontal da flor; f. fruto. g-i. Terminalia fagifolia (A. Fernandes s.n. EAC 2889) - g. face adaxial da folha; h. visão frontal da flor; i. fruto. j-1. Terminalia glabrescens (A.S.F. Castro 1067) - j. face adaxial da folha; k. visão frontal da flor; 1. fruto. m-o. Terminalia mameluco (A.S.F. Castro1621) - m. folha; n. infrutescência; o. fruto.

Figure 5 - a-c. Combretum monetaria (J.G. Carvalho-Sobrinho1861) - a. the adaxial leaf; b. frontal view of flower; c. fruit. d-f. Terminalia argentea (B. Dubs 1731) - d. the adaxial leaf; e. frontal view of flower; f. fruit. g-i. Terminalia fagifolia (A. Fernandes s.n. EAC 2889) - g. the adaxial leaf; $h$. frontal view of flower; i. fruit. j-1. Terminalia glabrescens (A. S. F. Castro 1067) - j. the adaxial leaf; k. frontal view of flower; 1. fruit. m-o. Terminalia mameluco (A. S. F. Castro1621) - m. the adaxial leaf; n. infrutescence; o. fruit.

\section{Terminalia L. Syst. Nat. 12. (2): 674. 1767.}

Árvore. Folhas alternas, geralmente aglomeradas no ápice dos ramos. Inflorescências em espigas ou panículas de espigas, terminais ou axilares. Flores andróginas ou unissexuadas, às vezes na mesma inflorescência. Hipanto inferior fusiforme, cilíndrico ou 4-5 anguloso; hipanto superior campanulado, subcampanulado, com 5 lobos desenvolvidos e agudos. Pétalas ausentes. Estames 10, inseridos em dois verticilos; anteras versáteis. Disco nectarífero geralmente bem desenvolvido, piloso. Fruto betulídeo, arredondado ou complanado, seco ou carnoso, coriáceo ou suberoso, geralmente $2-5$ alado.
5.1. Terminalia argentea Mart., Gen. Sp. Pl. 1: 43. 1824.

Fig. $5 \mathrm{~d}-\mathrm{f}$

Árvore 4-30 m alt., indumento glabro. Folhas 3,0-4,7 × 1,0-2,3 cm, lâmina elíptica, ápice agudo, base cuneada, argênteo-tomentosa na face abaxial; venação eucamptódroma-broquidódroma, 6-10 pares de nervuras secundárias; pecíolo 1-3 mm compr. Inflorescências $1,8-3,1 \mathrm{~cm}$ compr., espigas capitadas, axilares. Bractéola e botões florais não observados. Flores 2,1-3,0 × 1,2-1,5 $\mathrm{mm}$, esverdeadas a amareladas; hipanto inferior $0,9-1,2 \times 1,0 \mathrm{~mm}$, fusiforme; hipanto superior 1,2-2,0 × 1,5-1,5 mm, campanulado; lobos do cálice $0,9-1,2 \times 0,3-0,5 \mathrm{~mm}$, triangulares, reflexos; 
filetes do verticilo interno $2,5-4,0 \mathrm{~mm}$ compr.; filetes do verticilo externo $2,0-4,5 \mathrm{~mm}$ compr.; anteras $0,6-0,8 \times 0,4-0,5 \mathrm{~mm}$, orbiculares; disco nectarífero $0,7-0,9 \mathrm{~mm}$ compr., lobado, margem livre, pubescente; ovário $0,3-0,5 \times 0,2-0,4 \mathrm{~mm}$; estilete 3,5-5,0 $\mathrm{mm}$ compr., subulado; estigma truncado. Fruto 4,5-7,0 × 1,5-2,7 cm, 2-alado; alas $3,5-4,0 \times 1,5-2,4 \mathrm{~cm}$, arredondadas, mais largas que o corpo do fruto, às vezes apresentando uma terceira ala vestigial; região central 1,0-1,5 $\times$ 1,2-2,2 cm; pedicelo frutífero $15-23 \mathrm{~mm}$ compr. Material examinado: Pacoti, Serra de Baturité, 4.VI.1983, fr., A. Fernandes \& Matos (EAC 12021).

Material adicional: MINAS GERAIS: Paraopeba, EFLEX, 30.IX.1987, fl. e fr., F.A. da Silveira 10248 (VIC). MATO GROSSO DO SUL: Maracaju, Fazenda São João, 5.IX.1994, fl. e fr., B. Dubs 1731 (ESA).

Facilmente reconhecida pelas folhas argênteo-tomentosas na face abaxial, flores com os lobos do cálice reflexos e fruto 2-alado com alas arredondadas, mais largas que o corpo do fruto. Ocorre no Brasil, Peru, Paraguai e Bolívia (Stace 2010). Espécie rara no Ceará, foi registrada por uma só coleta, em floresta estacional semidecidual (Fig. 6). Foi coletada apenas com frutos em junho. Segundo Borges et al. (2012) esse táxon foi classificado como espécie ameaçada de extinção na categoria vulnerável.

5.2. Terminalia fagifolia Mart., Nov. Gen. Sp. (1):42, pl. 27. 1824.

Fig. $5 \mathrm{~g}-\mathrm{i}$

Árvores $14 \mathrm{~m}$ alt., indumento tomentoso e cinéreo. Folhas 3,0-4,3 × 9,0-1,5 cm, lâmina elíptica, ápice agudo ou arredondado, base cuneada; venação craspedódroma-eucamptódroma, 5-12 pares de nervuras secundárias; pecíolo 1-2 mm compr. Inflorescências 1,9-3,2 cm compr., espigas paucifloras, axilares. Bractéola não observada; botão floral 2,5-3,0 × 1,5-2,0 mm, elipsoidearredondado, tomentoso. Flores 3,5-4,0 × 3,0-3,5 $\mathrm{mm}$, amareladas, tomentosas; hipanto inferior $1,0-2,0 \times 1,0-1,2 \mathrm{~mm}$, elíptico; hipanto superior 2,0-2,5 ×3,0-3,5 mm, campanulado; lobos do cálice $1,2-1,5 \times 0,5-0,8 \mathrm{~mm}$, triangulares, eretos; filetes do verticilo interno $2,5-5,0 \mathrm{~mm}$ compr., filetes do verticilo externo $2,0-4,0 \mathrm{~mm}$ compr.; anteras $0,6-0,8$ $\times 0,5-0,6 \mathrm{~mm}$, cordiformes; disco nectarífero $0,8-1$ $\mathrm{mm}$ compr., aneliforme, margem livre, tomentoso; ovário $0,2-0,4 \times 0,2-0,3 \mathrm{~mm}$; estilete $2,5-3,5 \mathrm{~mm}$ compr., filiforme; estigma truncado. Fruto $1,3-2,0$ $\times 0,7-0,9 \mathrm{~cm}, 2$-alado, tomentoso; alas 0,3-0,8 $\times$ $0,5-0,7 \mathrm{~cm}$, arredondadas; região central $0,2-0,4 \times$ $0,7-0,9 \mathrm{~mm}$; pedicelo frutífero $14-16 \mathrm{~mm}$ compr.

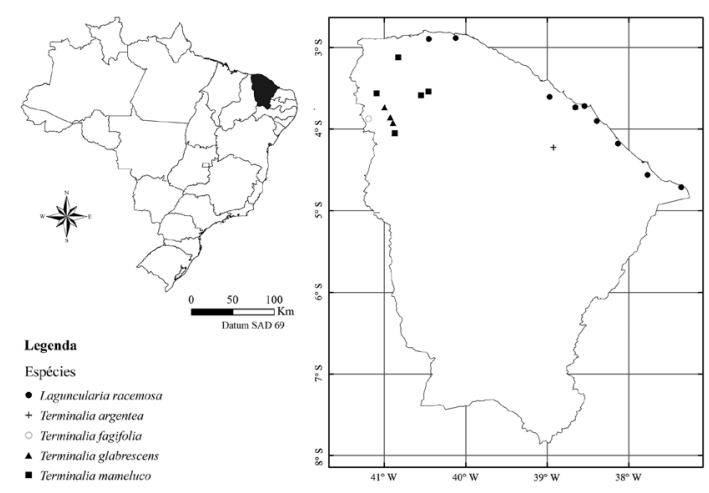

Figura 6 - Distribuição de Combretaceae no Ceará, Brasil: - Laguncularia racemosa; + Terminalia argentea; ○ T. fagifolia; $\boldsymbol{\Delta}$ T. glabrescens; $\mathbf{\square}$ T. mameluco.

Figure 6-Distribution of Combretaceae in Ceará state, Brazil: • Laguncularia racemosa; + Terminalia argentea; ○ T. fagifolia; \ T. glabrescens; $\mathbf{\square}$ T. mameluco.

Material examinado: Tianguá, Serra da Ibiapaba, 5.IX.1976, fr., A. Fernandes (EAC 2889).

Caracterizada pelo indumento tomentoso e cinéreo cobrindo folhas, botões, flores e frutos; lobos do cálice eretos e fruto 2-alado. Ocorre no Brasil e Bolívia (Stace 2010). Registrada em vegetação de carrasco (Fig. 6). Coletada com flores nos meses de outubro e novembro, e com frutos em setembro e novembro. Popularmente conhecida como cascudo.

5.3. Terminalia glabrescens Mart., Flora 20(2): 124. 1837. Fig. 5j-1

Árvore $12 \mathrm{~m}$ alt., indumento coberto por tricomas ferrugíneos. Folhas 3,2-5,5 × 2,1-2,9 $\mathrm{cm}$, lâmina obovada, glabra, ápice agudo ou retuso, base cuneada; venação eucamptódroma ou às vezes eucamptódroma-broquidódroma, $5-8$ pares de nervuras secundárias; pecíolo 2,5-3,0 mm compr. Inflorescências 5,8-6,9 cm compr., espigas densifloras, axilares. Bractéola e botões florais não observados. Flores 2,5-3,5 × 2,5-3,0 $\mathrm{mm}$, brancas ou esverdeadas; hipanto inferior 1,0-1,5 × 1,0-1,5 mm, viloso-tomentoso; hipanto superior $1,0-2,5 \times 2,5-3 \mathrm{~mm}$, campanulado; lobos do cálice $0,5-0,6 \times 0,6-0,8 \mathrm{~mm}$, curtotriangulares; verticilo interno $2,8-3,5 \mathrm{~mm}$ compr., filetes do verticilo externo 2,5-3,0 mm compr.; anteras $0,4-0,5 \times 0,5-0,6 \mathrm{~mm}$, orbiculares; disco nectarífero $0,4-0,5 \mathrm{~mm}$ compr., aneliforme, margem livre, pubescente; ovário 0,4-0,6 $\times 0,3-0,4 \mathrm{~mm}$; estilete $3,5-4,0 \mathrm{~mm}$ compr., filiforme; estigma obtuso. Fruto 1,8-2,2 $\times 0,5-0,7$ $\mathrm{cm}, 5$-alado, alas desiguais, 2 alas mais largas que 
o corpo do fruto e 3 menores; região central ca. 1 $\times 1 \mathrm{~mm}$; pedicelo frutífero $1-2 \mathrm{~cm}$ compr.

Material examinado: São Benedito, $2 \mathrm{~km}$ da cidade, entrada para Guaraciaba, 9.IX.2011, fl. A.S.F. Castro 1067 (EAC). Tianguá, margem da estrada, 23.IX.1978, fr., A. Fernandes \& P. Bezerra (EAC 5002). Ubajara, em local não determinado, 23.IX.1978, fl., A. Fernandes \& P. Bezerra (EAC 5021).

É reconhecida pelos ramos com coloração ferrugínea, lobos do cálice curto-triangulares e eretos e fruto com cinco alas desiguais. Ocorre no Brasil, Bolívia e Paraguai (Stace 2010). No Ceará, foi registrada em vegetação de carrasco e floresta estacional semidecidual (Fig. 6). Coletada com flores e frutos em setembro. Nome popular: mirindiba.

\subsection{Terminalia mameluco Pickel, Arq. Bot. Estado} São Paulo 3: 200. 1958.

Fig. $5 \mathrm{~m}-\mathrm{o}$

Árvores $12 \mathrm{~m}$ de alt. Folhas 7,7-8,0 × 3,3-3,8 $\mathrm{cm}$, lâmina obovada, glabra, ápice acuminado ou subagudo, base cuneada; venação broquidódroma, 5-8 pares de nervuras secundárias; pecíolo 9-15 $\mathrm{mm}$ compr. Inflorescências 3,6-5,2 cm compr., espigas densifloras, axilares. Bractéola única, 2,5-3,0 $\times$ 0,8-1,0 mm, cimbiforme; botão floral 3,0-4,5 $\times$ $1,5-2,5 \mathrm{~mm}$, capitado. Flores 5,0-6,0 $\times 2,0-3,0 \mathrm{~mm}$, amareladas; hipanto inferior 3,0-3,5 × 1,0-1,5 mm, elíptico; hipanto superior 2,0-2,5 × 2,0-3,0 mm, campanulado; lobos do cálice $0,5-0,6 \times 0,5-0,8$ $\mathrm{mm}$, triangulares, reflexos; filetes do verticilo interno $3,0-3,5 \mathrm{~mm}$ compr., filetes do verticilo externo $3,5-4,0 \mathrm{~mm}$ compr.; anteras $0,5-0,8 \times 0,5-0,6 \mathrm{~mm}$, cordiformes; disco nectarífero $0,5-1,0 \mathrm{~mm}$ compr., aneliforme, margem livre, glabrescente a pubescente; ovário $0,8-1,0 \times 0,3-0,5 \mathrm{~mm}$; estilete $5,0-6,0 \mathrm{~mm}$ compr., linear; estigma truncado. Fruto $1,8-2,0 \times$ 3,1-3,8 cm, 2-alado; alas 0,9-1,2 × 1,4-2,0 mm, oblongas ou subtriangulares; região central 1,6-2,0 $\times 0,5-0,7 \mathrm{~mm}$; pedicelo frutífero $4,2-4,5 \mathrm{~mm}$ compr. Material examinado: Granja, Palmeira sopé da Serra de Ubatuba, 10.IX.2005, fl., A.S.F. Castro 1621 (EAC). Meruoca, Algodões, 27.V.2003, fr., A. Fernandes (EAC 32544). Viçosa do Ceará, Gen. Tibúrcio, encosta da Serra da Ibiapaba, 8.VI.2007, A.S.F. Castro 1947 (EAC).

Terminalia mameluco pode ser facilmente reconhecida pelas folhas obovadas e glabras; flores com lobos do cálice reflexos e fruto 2-alado, com alas oblongas ou subtriangulares. A espécie é endêmica do leste do Brasil (Marquete 2012). No Ceará foi encontrada em vegetação de mata seca e mata úmida (Fig. 6). Coletada com flores nos meses de janeiro, setembro e dezembro e com frutos nos meses de maio e junho. Conhecida popularmente como mameluco, pelada.

\section{Agradecimentos}

Ao CNPq, a bolsa concedida ao primeiro autor (Processo 136745/2011-3); à FUNCAP, o auxílio na compra dos equipamentos usados para a realização deste trabalho; aos Projetos INCT Flora Virtual de Plantas e Fungos, SISBIOTA e "Efetividade de UCs Federais do estado do Ceará na conservação biológica do semiárido brasileiro (Ubajara e Aiuaba)", o apoio financeiro para as coletas de campo; aos curadores e funcionários dos Herbários ESA, HST, HVASF, MO, R e VIC, o envio das coleções para análise; à pesquisadora Nilda Marquete do Jardim Botânico do Rio de Janeiro, o envio de publicações Flora Neotropical - Combretaceae; a Felipe Martins Guedes, as contribuições na elaboração das ilustrações.

\section{Referências}

Angiosperm Phylogeny Group III. 2009. An update of the Angiosperm Phylogenetic Group classification for the orders and families of flowering plants: APG III. Botanical Journal of the Linnean Society 161: 105-121.

Borges, R.; Moraes, M.A.; Monteiro, N.P.; Bevacqua, A.M.; Martinelli, G. \& Marquete, N.F. 2012. Available data and risk assessment of the Brazilian threatened species of Combretaceae. Rodriguésia 63: 31-38.

Exell, A.W. \& Stace, C.A. 1966. Revision of the Combretaceae. Boletim da Sociedade Brotheriana 40: 5-25.

Hijmans, R.J.L.; Guarino, A.; Jarvis, R.; O’Brien, P.; Mathur, C.; Bussink, M.; Cruz, I. Barrantes, \& Rojas. E. 2005. DIVA-GIS. Ver. 5.2. Disponível em <http:diva-gis.org>. Acesso em 12 abril 2014.

IBGE. 2012. Manual técnico da vegetação brasileira. $2^{\mathrm{a}}$ ed. Disponível em <ftp://geoftp.ibge.gov.br/ documentos/recursos_naturais/manuais_tecnicos/ manual_tecnico_vegetacao_brasileira.pdf $>$. Acesso em 16 abril $201 \overline{4}$.

IPNI. 2013. The International Plant Names Index. Disponível em $<$ http://www.ipni.org $>$. Acesso em 3 maio 2013.

Linsigen, L.V.; Cervi, A.C. \& Guimarães, O. 2009. Sinopse taxonômica da família Combretaceae R. Brown na Região Sul do Brasil. Acta Botanica Brasilica 23: 738-750.

Loiola, M.I.B. \& Sales, M.F. 1996. Estudos taxonômicos do gênero Combretum Loefl. (Combretaceae R. Br.) em Pernambuco - Brasil. Arquivos do Jardim Botânico do Rio de Janeiro 34: 173-190.

Loiola, M.I.B.; Rocha, E.A.; Baracho, G.S. \& Agra, M.F. 2009. Flora da Paraíba: Combretaceae. Acta Botanica Brasilica 23: 330-342. 
Marquete, N.F.S. 1984. Combretaceae do estado do Rio de Janeiro. Subtribo Terminaliineae. Rodriguésia 36: 91-104.

Marquete, N.F.S. 1995. Combretum Loefl. do Brasil Sudeste (Combretaceae). Arquivos do Jardim Botânico do Rio de Janeiro 33: 55-107.

Marquete, N.F.S. 2012. Combretaceae. In: Lista de Espécies da Flora do Brasil. Jardim Botânico do Rio de Janeiro. Disponível em <http:// floradobrasil.jbrj.gov.br/2012/FB000090> Acesso em 20 março 2012.

Marquete, N.F.S. \& Valente, M.C. 1997. Combretaceae. In: Marques, M.C.M. \& Martins, H.F. (orgs.). Flora do estado do Rio de Janeiro. Albertoa 4: 13-51.

Marquete, N.F.S. \& Valente, M.C. 2010. Combretaceae. In: Forzza, R.C. et al. (org.). Catálogo de plantas e fungos do Brasil. Vol. 1. Jardim Botânico do Rio de Janeiro, Rio de Janeiro. Pp. 864-866.

Marquete, N.F.S.; Teixeira, J. \& Valente, M.C. 2003. Terminalia L. (Combretaceae) na Região Sudeste do Brasil. Bradea 16: 99-123.

Maurin, O.; Chase M.K.; Jordaan, M. \& Vanderbank, M. 2010. Phylogenetic relationships of Combretaceae inferred from nuclear and plastid DNA sequence data: implications for generic classification. Botanical Journal of the Linnean Society 162: 453-476.

MOBOT 2013. Tropicos.org. Missouri Botanical Garden. Disponível em $<$ http://www.tropicos.org $>$. Acesso em 25 outubro 2013.

Radford, A.E.; Dickson, W.C.; Massey, J.R. \& Bell, C.R. 1974. Vascular plant systematics. Harper \& Row, New York. 891p.
Stace, C.A. 2004. Combretaceae. In: Smith, N.; Mori, S.A.; Henderson, A.; Stevenson D.W. \& Heald, S.V. (eds.). Flowering plants of the Neotropics. Princeton University Press, Princeton. Pp. 110-111.

Stace, C.A. 2010. Combretaceae. Flora Neotropica 107. The New York Botanical Garden Press, New York. 369p.

Spjut, R.W. 1994. A systematic treatment of fruit types. Vol. 70. The New York Botanical Garden Press, New York. 182p.

Stearn, W.T. 1992. Botanical latin. $4^{\text {th }}$ ed. David \& Charles Book, Redwood Press England Ltd. 546p.

Sytsma, J.K.; Litt, A.; Zjhra, M.L.; Pires, J.C.; Nepokroeff, M.; Conti, E.; Walker, J. \& Wilson, P.G. 2004. Clades, clocks and continents: Historical and biogeographical analysis of Myrtaceae, Vochysiaceae, and relatives in the Souther Hemisphere. International Journal of Plant Sciences 165: 85-105.

Tan, F.X.; Shi, S.H.; Zhong, Y.; Gong, X.; Wang, Y.G. 2002. Phylogenetic relationships of Combretoideae (Combretaceae) inferred from plastid, nuclear gene and spacer sequences. Journal of Plant Research 115: 475-481.

Thiers, B. [continuously updated]. 2012. Index Herbariorum: a global directory of public herbaria and associated staff. New York Botanical Garden's Virtual Herbarium. Disponível em $<$ http:// sweetgum.nybg.org/ih/>. Acesso em 28 abril 2012.

Weaver, P.L. 1991. Buchenavia capitata (Vahl.) Eichler: Granadillo. SO-ITF-SM-43, Departmente of Agriculture, Forest Service, Southern Forest Experiment Station, New Orleans. 7p.

\footnotetext{
Lista de exsicatas examinadas

Aguiar, D. EAC 5013(1.1); Alencar, A.L. EAC 38988(1.1); Almeida, L. EAC 2931(3.1), EAC 3121(2.3); Andrade, A. EAC 30585(2.7); Andrade, I.M. EAC 21862(2.7), EAC 21866(2.7) Andrade Neto, M. EAC 15776(2.5), EAC 15809(2.6), EAC 21252(2.7); Araújo, D. 1409(2.5); Araújo, F.S. 4(2.3), 73(1.2), 336(2.7), 338(2.3), 380(2.7), 422(2.3), 507(1.2), 514(1.2), 753(2.3), 1128(2.3), 1334(2.7), 1473(2.8), 1516(2.7), 1517(2.7), 1600(1.2), EAC 17272(2.7), EAC 15728(2.3); Azevedo, D.V. 2(3), 5(2.7), 6(2.7), 15(2.7); Barboza, A. EAC 15160(1.1); Barros, E.O. 163(2.7), EAC 25694(2.7); Bezerra, P. 118(2.7), 301(2.2), 391(5.4), 545(2.4), EAC 814(2.5), EAC 1802(1.1), EAC 3071(4), Cardoso, H. EAC 33869(2.7); Carvalho, A.M.M. EAC 46475(2.7); Carvalho-Sobrinho, J.G. 1968(2.3); Castro, A.S.F. 232(2.6), 338(4), 585(1.1), 703(1.1), 790(2.2), 837(2.3), 852(1.1), 930(2.1), 974(2.1), 1031(2.3), 1046(1.2), 1067(5.3), 1091(1.1), 1151(2.6), 1534(2.6), 1621(5.4), 1846(1.2), 1848(2.6), 1851(2.7), 1920(1.1), 1947(5.4), 2336(2.7), 2397(2.3), 2660(2.2), 2459(2.7), 2566(5.3); Cavalcanti, F.S. 37(2.8), 551(2.6), 867(1.1), EAC 12892(2.7), 15688(2.6), EAC 16607(4), 23180(1.1), EAC 23843(1.1), EAC 23910(2.7), 24396(2.5), EAC 24399(1.1), EAC 24980(1.1), EAC 25159(2.5), EAC 29254(2.3); César, S. 34(2.2); Cláudio, L. EAC 21289(2.7); Costa, R.C. 31(2.8), 147(2.8), 233(2.8), 269(2.7), 298(2.3), 311(1.2), 314(2.3), 326(2.5), 430(2.7); Cotarelli, V.M. 1725(2.9), 1808(2.5); Ducke, A. EAC 1561(2.3), 2451(2.7); Farias, D. EAC 39603(2.7); Félix, L.P. EAC 19031(1.1); Fernandes, A. EAC 1037(3), EAC 1118(2.3), EAC 1176(2.3), EAC 1410(2.2), EAC 1809(2.5), EAC 1853(2.7), EAC 1912(2.5), EAC 1980(2.3), EAC 2098(2.7), EAC 2100(2.7), EAC 2213(4), EAC 2441(2.1), EAC 2445(2.8), EAC 2575(2.3), EAC 2576(2.7), EAC 2889(5.2), EAC 2894 (5.2), EAC 2941(5.2), EAC 3056(5.2), EAC 3074(3), EAC 3196(2.8), 3205(2.8), 3918(2.2), 3922(2.8), EAC 3944(2.2), EAC 4002(2.1), EAC 4248(1.1), EAC 5002(5.3), EAC 5021(5.3), EAC 5974(2.7), EAC 6080(2.7), EAC 8281(2.4), EAC 8364(2.3), EAC 8536(2.7), EAC 8900(2.2), EAC 9866(2.7), EAC 9868(2.8), EAC 10308(2.8), EAC 10744(1.2), EAC 12021(5.4), EAC 12025(2.2), EAC 12446(2.7), EAC 12471(2.7), EAC 12717(2.8), EAC 12958(2.6), EAC 13177(2.1), EAC 13275(2.1), EAC 13278(2.5), EAC 13298(2.5), EAC 14524(3), EAC
} 
14837(1.1), EAC 14933(2.3), EAC 15130(2.8), EAC 15314(2.7), EAC 15315(2.7), EAC 15651(2.6), EAC 16010(1.2), EAC 16152(2.3), EAC 16.201(2.6), EAC 16326(2.7), EAC 21394 (2.7), EAC 27743(2.5), EAC 27750(1.1), EAC 27828(2.1), EAC 28496(2.6), EAC 28695(2.5), EAC 29062(1.1), EAC 32290(5.4), EAC 32295(5.4), EAC 32507(2.4), EAC 32544(5.4), EAC 32879(2.2), EAC 32881(2.2), EAC 32882(2.7), EAC 32918(1.1), EAC 33865(2.7), EAC 33866(2.8), EAC 48572(2.7); Figueiredo, M.A. 193(2.5), 208(2.3), 449(2.5), 636(2.7), EAC 8875(2.5), EAC 15197(1.1), EAC 15990(2.3), EAC 16121(2.8), EAC 19805(4), EAC 20081(2.3), EAC 21366(2.7), EAC 23393(2.5), EAC 2411(2.6), EAC 25501(2.7), EAC 25631(2.3); Frei Pinto, M. EAC 44598(4); Freitas, B. EAC 16843(2.7); Gentry, A. 50114(2.3), 50147(2.8), 50197(2.1); Gomes, O.M. EAC 22340(2.3); Landim, B. 2(2.7); Lemos, J.R. 157(2.5), 305(2.3); Lima, J.W. EAC 5029(4), EAC 3795(4), EAC 3798(3); Lima, J.R. 74(2.7); Lima-Verde, L.W. 222(2.8), 283(2.5), 958(2.8), 959(1.2), 1111(2.3), 1145(1.1), 1183(2.8), 1185(2.7), 1746(1.1), 1749(1.1), 1825(1.1), 1902(1.1), 1997(1.1), 2020(1.1), 2267(1.1), 2989(2.8), 3060(2.5), 